\title{
Pengembangan Media Pembelajaran Berbasis Android pada Pemrograman Dasar Pascal
}

\author{
Taufan Anwari1 ${ }^{*}$, Ali Shodiqin ${ }^{2}$, Andi Priyolistiyanto ${ }^{3}$ \\ ${ }^{123}$ Fakultas Pendidikan Matematika Ilmu Pengetahuan Alam dan Teknologi Informasi, Universitas PGRI \\ Semarang, Semarang, Indonesia
}

\begin{abstract}
Abstrak
Kata Kunci:

Penelitian ini bertujuan untuk mengembangkan media pembelajaran berbasis Android pada pembelajaran tersebut dan mengetahui kelayakan,perbedaan hasil belajar siswa dan pengembangan dari media pembelajaran yang dikembangkan.Penelitian ini menggunakan model pengembangan ADDIE yaitu: (1) Analyze (analisis), (2) Design (desain atau perancangan), (3) Development Android, Media Pembelajaran, Pemrograman Dasar Pascal (pengembangan), (4) Implementation (implementasi), dan (5) Evaluation (evaluasi). Penelitian dilakukan di SMK Negeri 9 Semarang dengan melibatkan 35 responden pada bulan september 2019 untuk mengetahui tingkat kelayakan dan peningkatan hasil belajar media pembelajaran berbasis Android ini. Hasil dari penelitian pengembangan ini adalah: Tingkat kelayakan media pembelajaran berbasis Android Pemrograman pascal untuk siswa kelas X oleh ahli media 1 diperoleh rata-rata keseluruhan sebesar 93\% dengan kategori "Sangat Layak", ahli media 2 diperoleh rata-rata keseluruhan sebesar 76\% dengan kategori "Layak".Oleh ahli materi diperoleh rata-rata keseluruhan sebesar 76,56\% dengan kategori "Layak", oleh guru mata pelajaran diperoleh rata-rata keseluruhan sebesar 77,47\% dengan kategori "Layak", dan pengujian oleh peserta didik diperoleh rata-rata keseluruhan sebesar 81,4\% dengan kategori "Sangat Layak". Rata-rata keseluruhan responden sebesar 80,8\% dengan kategori "Layak" sehingga dapat disimpulkan bahwa media pembelajaran berbasis Android yang dikembangkan "Layak" digunakan. Sedangkan pada kemampuan Aplikasi Media pembelajaran berbasis android pada pemrograman dasar pascal untuk siswa kelas X RPL SMK Negeri 9 Semarang dengan model pembelajaran discovery learning mengalami perbedaan yang signifikan yang di dukung dengan uji-t, dibandingkan dengan pembelajaran tanpa aplikasi edukatif berbasis android.
\end{abstract}

\begin{abstract}
This research aims to develop an Android-based learning learning media and knowing the feasibility of student learning outcomes and the development of learning media developed. The research use ADDIE as development model, that is: (1) Analyze, (2) Design, (3) Development, (4) Implementation, and (5) Evaluation. The research is

Keywords:

Android, Learning Media, Pascal Basic Programming done at grade X public 9 Semarang Vocational High School with 35 respondents from until september 2019 to knowing the feasibility of learning media based Android that have been developed. The result of research are: Level of learning media feasibility android besed Pascal programming for X-grade students by media experts 1 acquied overall average of 93\% with the category "very worthy", by media expert 2 acquired overall average of 76\% with the category "worthy". by material experts an overall average of 76,56\% with the category "worthy",by a teacher of subject obtained an overall average of 77,47\% with the category "worthy", and testing by learners, gained an overall average of $81,4 \%$ with the category "very worthy". The overall average of the respondents was $808 \%$ with the category "worthy", sothat it can be concluded that the learning media based on android, that developed "wothy" is used.While on the ablility of android based learning application on basic programming pascal for students grade X RPL of public 9 Semarang vocational high school with learning discovery models significant diffrences are supported with the test-t, compared to learning without an educative application based on android.
\end{abstract}

\footnotetext{
* Corresponding author. 


\section{PENDAHULUAN}

Pada awal sejarah pembelajaran, media hanyalah merupakan alat bantu yang dipergunakan oleh seorang guru untuk menerangkan pelajaran. Alat bantu yang mula-mula digunakan adalah bantu visual, yaitu berupa sarana yang dapat memberikan pengalaman visual kepada siswa, antara lain untuk mendorong motivasi belajar, memperjelas dan mempermudah konsep yang abstrak, dan mempertinggi daya serap dalam belajar. Pada abad ke-20 lahirlah alat bantu audio visual yang terutama pengalaman yang kongkrit untuk menghindari verbalisme Dalam usaha memanfaatkan media sebagai alat bantu. Edgar Dale mengadakan klasifikasi menurut tingkat dari yang paling kongkrit ke paling abstrak (Hafid, 2011). Media pengajaran merupakan kebutuhan yang tidak dapat dielakkan dalam rangka menyukseskan program belajar siswa agar dapat tercapai perubahan tingkah laku yang diharapkan. Konsekuensinya, guru hendaknya memiliki peran dalam memilih media yang tepat dan melakukan pemilihan itu berdasarkan teknik dan langkah-langkah yang benar (Mahnun, 2012). Menurut Amirullah (2017)Media pembelajaran merupakan salah satu komponen sumber belajar yang penting. Berbagai bentuk dan jenis media pembelajaran yang digunakan oleh guru dapat menjadi sumber ilmu pengetahuan bagi siswa. Dengan semakin meluasnya kemajuan di bidang komunikasi dan teknologi, serta diketemukannya dinamika proses belajar, maka pelaksanaan kegiatan pendidikan dan pengajaran semakin menuntut dan memperoleh media pembelajaran yang bervariasi secara luas Menurut Adam (2015) media pembelajaran adalah segala sesuatu baik berupa fisik maupun teknis dalam proses pembelajaran yang dapat membantu guru untuk mempermudah dalam menyampaikan materi pelajaran kepada siswa sehingga memudahkan pencapaian tujuan pembelajaran yang telah dirumuskan. Menurut Tafonao (2018) media pembelajaran adalah alat bantudalam proses belajar mengajaruntuk merangsang pikiran, perasaan, perhatian dan kemampuan atau ketrampilan pembelajar sehingga dapat mendorong terjadinya proses belajar.Media pembelajaran yang memanfaatkan teknologi telepon seluler disebut dengan mobile learning. Mobile learning merupakan salah satu alternatif pengembangan media pembelajaran. Mobile learning dapat dipandang sebagai suatu sistem yang dipandang dalam upaya meningkatkan kualitas pembelajaran dengan berupaya menembus keterbatasan ruang dan waktu (Rossi \& Biddle 1966: 3). Penelitian yang dilakukan oleh Thitiporn Sittichailapa, dkk dalam proceedia tahun 2015. Dengan judul The Development of Model Learning Media of Sorting Algorithm. Penerapkan alat pembelajaran ini membuat siswa dapat memahami materi yang dimaksudkan dalam waktu yang lebih singkat dan dengan kesenangan. Penelitian yang dilakukan oleh Mostafa Al-Emran, dkk dalam jurnal Computers in Human Behavior tahun 2016 dengan judul Investigating attitudes towards the use of mobile learning in higher education. Hasil penelitian menunjukkan adanya perbedaan yang signifikan antara sikap siswa terhadap M-learning sehubungan dengan kepemilikan, negara, dan usia smartphone mereka. Selanjutnya, hasil menunjukkan bahwa $M$ learning dapat menjadi salah satu teknologi pedagogis yang menjanjikan untuk dipekerjakan di lingkungan pendidikan tinggi di saudi arabia.

Dari pemaparan tersebut maka penelitian ini bertujuan untuk mengetahui 1) perkembangan dari produk media pembelajaran berbasis Android dalam bentuk aplikasi edukatif sebagai media pembelajaran pada mata pelajaran pemrograman dasar pascal untuk siswa Kelas X SMK Negeri 9 Semarang tahun ajaran 2019/2020; 2) hasil belajar siswa setelah penerapan metode aplikasi edukatif berbasis android pada mata pelajaran pemrograman dasar pascal dengan model pembelajaran discovery learning untuk kelas X SMK tahun ajaran 2019/2020; 3) Mengembangkan produk media pembelajaran berbentuk aplikasi edukatif berbasis android sebagai media pembelajaran Pemrograman dasar pascal untuk siswa kelas X SMK tahun ajaran 2019/2020; 4) Melihat perbedaan hasil belajar siswa setelah melalui penerpan metode aplikasi edukatif berbasis android pada mata pelajaran Pemrograman Dasar pascal dengan model pembelajaran discovery learning untuk kelas X SMK Negeri 9 Semarang tahun ajaran 2019/2020. Dan diharapkan dari adanya penelitian ini dapat memberikan manfaat diantaranya yaitu: 1) Bagi perkembangan ilmu teknologi informasi pada umumnya dan bagi bidang rekayasa perangkat lunak (RPL) pada khususnya, terutama dapat memberikan masukan-masukan baru dalam Pengembangan Aplikasi edukatif berbasis android sebagai media pembelajaran pemrograman disar pascal; 2) Hasil penelitian ini dapat membantu Guru dan siswa mengenai media pembelajaran yang dapat membantu mereka untuk lebih mudah dalam memahami materi pelajaran dalam bentuk aplikasi di smartphone. Penggunaan media pembelajaran yang variatif dan inovatif di sekolah diharapkan akan mempengaruhi proses belajar siswa, dan apabila proses belajar baik maka diharapkan prestasi yang dapat diraih oleh siswa juga dapat meningkat. 


\section{METODE PENELITIAN}

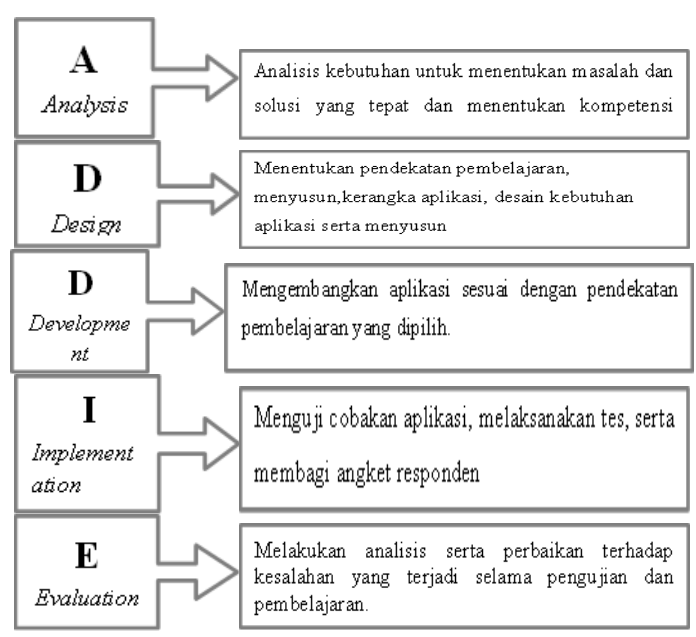

Sumber: Dick and Carry (1996)

Gambar 1. Model ADDIE

ADDIE merupakan singkatan dari Analysis, Design, Development or Production, Implementation or Delivery and Evaluations (Endang Mulyatiningsih, 2013: 199), berikut ini adalah tahapannya:

Tahap pertama dari model ADDIE yaitu Tahap Analysis atau analisis. Tujuan dari tahapan analisis adalah untuk mengetahui kebutuhan awal dalam mengembangkan media pembelajaran ini. Dalam mengembangkan media ini diperlukan analisis kebutuhan yaitu: (1) Analisis Kebutuhan Pengguna, (2) Analisis Konten atau Isi, dan (3) Analisis Kebutuhan Hardware dan Software.

Tahap kedua dari model ADDIE adalah Tahap Design atau perancangan. Pada tahap ini mulai dirancang aplikasi edukatif yang akan dikembangkan sesuai hasil analisis yang dilakukan sebelumnya.Selanjutnya, tahap perancangan dilakukan dengan menentukan unsur unsur yang diperlukan dalam aplikasi edukatif seperti penyusunan desain kebutuhan aplikasi dan kerangka aplikasi.

Tahap ketiga yaitu Tahap Development atau pengembangan merupakan tahap realisasi produk. Pada tahap ini pengembangan aplikasi edukatif dilakukan sesuai dengan rancangan. Setelah itu,aplikasi tersebut akan divalidasi oleh dosen ahli dan guru. Pada proses validasi, validator menggunakan instrumen yang sudah disusun pada tahap sebelumnya.Validasi dilakukan untuk menilai validitas isi dan konstruk. Validator diminta memberikan penilaian terhadap aplikasi yang dikembangkan berdasarkan butir aspek kelayakan aplikasi serta memberikan saran dan komentar berkaitan dengan isi aplikasi yang nantinya akan digunakan sebagai patokan revisi perbaikan dan penyempurnaan aplikasi.

Tahap keempat adalah Tahap Implementation atau implementasi. Implementasi dilakukan secara terbatas pada sekolah yang ditunjuk sebagai tempat penelitian. Guru kelas melakukan pembelajaran dengan bantuan aplikas yang sudah dikembangkan.Peneliti bertugas sebagai observer dan mencatat segala sesuatu pada lembar observasi yang dapat digunakan sebagai perbaikan aplikasi. Setelah proses pembelajaran selesai, peserta didik melakukan tes dengan menggunakan soal yang sudah disediakan.

Tahap terakhir yaitu Tahap Evaluation. Pada tahap ini, peneliti melakukan revisi terakhir terhadap aplikasi yang dikembangkan berdasarkan masukan yang didapat dari angket respon atau catatan lapangan pada lembar observasi. Hal ini bertujuan agar aplikasi yang dikembangkan benar-benar sesuai dan dapat digunakan oleh sekolah yang lebih luas lagi.

\section{ANALISIS DAN PEMBAHASAN}

Penelitian ini menghasilkan produk Hasil yang diperoleh dari penelitian dan pengembangan ini adalah media pembelajaran berupa aplikasi Android pada pemrograman dasar Pascal kelas X SMK Negeri 9 Semarang. Aplikasi yang dihasilkan yaitu berbentuk file dengan ekstensi apk dan diinstal di smartphone dengan sistem operasi Android. Hasil pengembangan yang dihasilkan melalui tahap-tahap yang digunakan dalam model pengembangan ADDIE (Analysis, Design, Development, Implementation, dan Evaluation). Produk yang dikembangkan disajikan pada Gambar-Gambar sebagai berikut: 
Halaman splash screen dan menu uatamamerupakan tampilan awal yang terbuka secara otomatis ketika membuka aplikasi sebelum masuk ke menu utama. Berikut adalah tampilan dari splash screen. Supaya setiap unsur yang terdapat dalam aplikasi dapat berjalan sesuai fungsinya
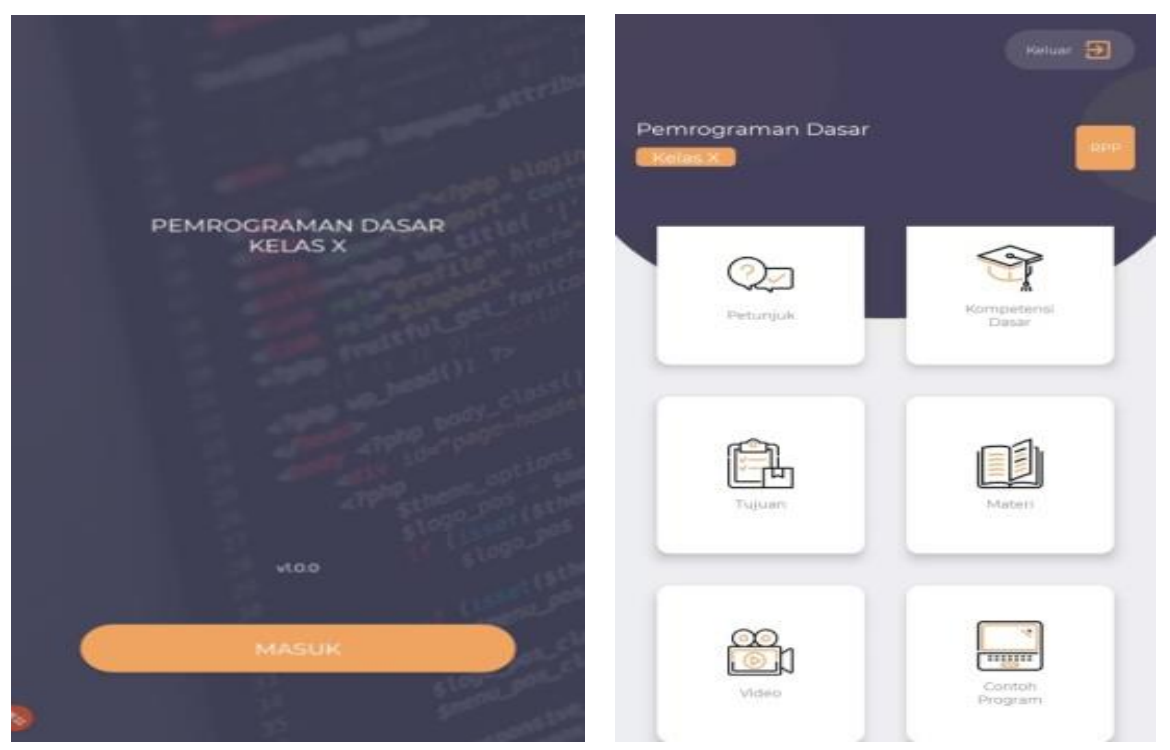

Gambar 2. Halaman Splash Screen dan Menu Utama

Halaman RPP yang ditampilkan pada Gambar 3. Merupakan halaman yang menampilkan recana pembelajaran, supaya pengguna dapat memahami recana pembelajaran yang akan di sampaikan kepada peserta didik.
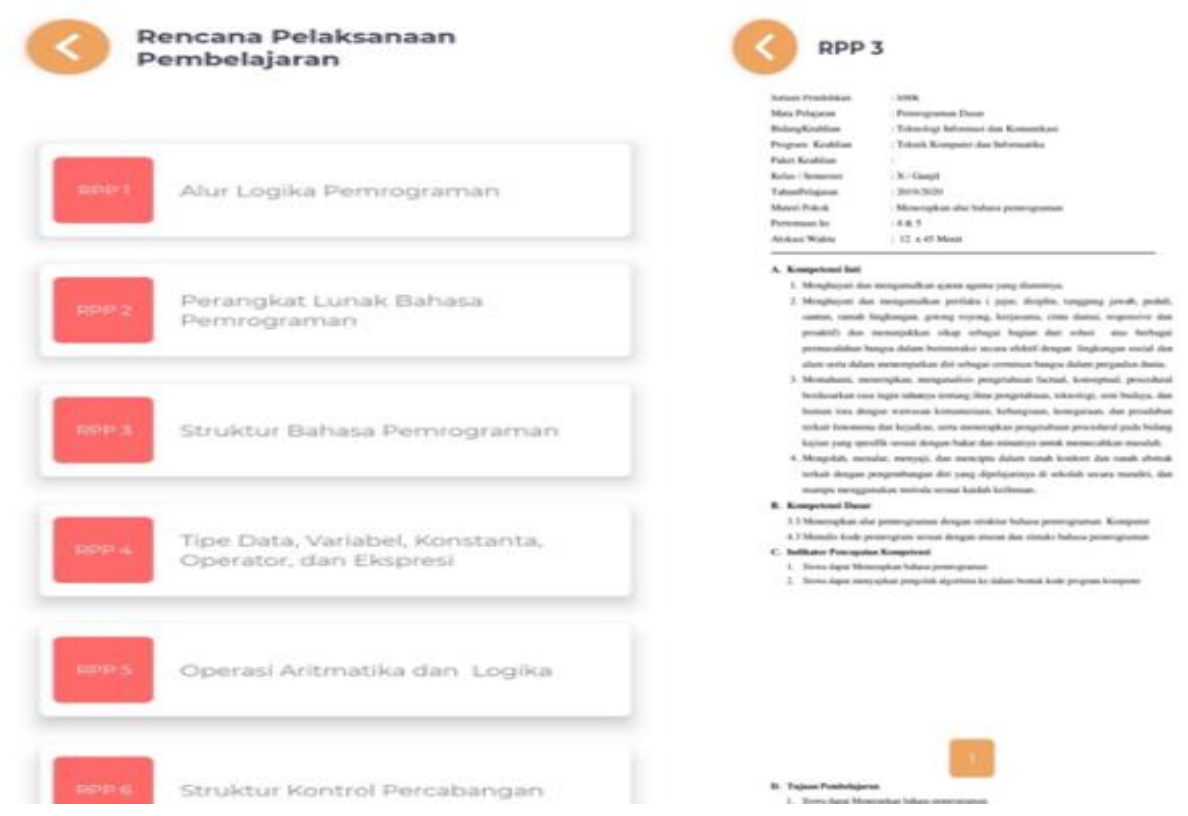

Gambar 3. Halaman RPP dan Isi RPP

Halaman petunjuk yang ditampilkan pada Gambar 4. merupakan halaman yang menampilkan petunjuk penggunaan aplikasi, supaya pengguna dapat memahami cara menggunakan aplikasi. 


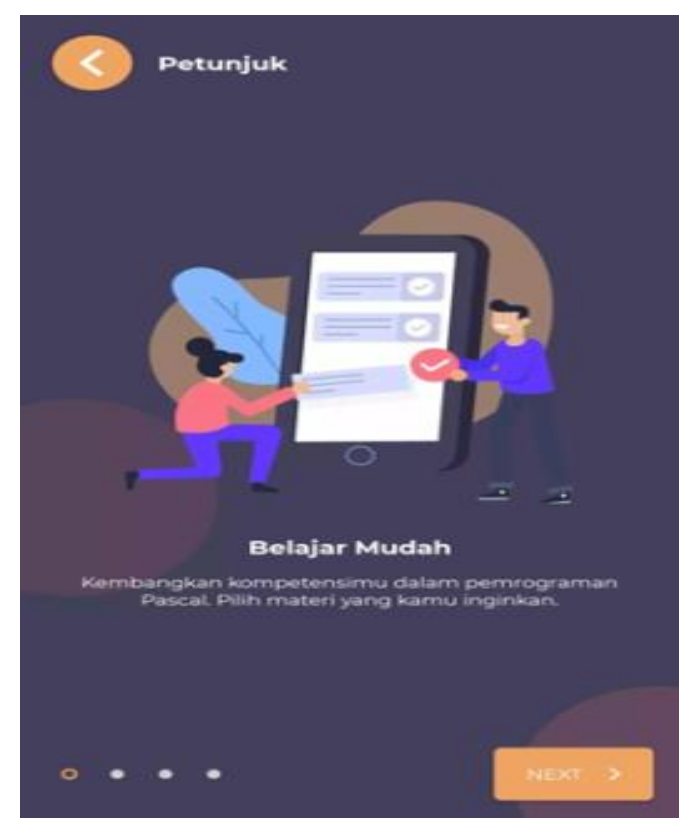

Gambar 4. Petunjuk Aplikasi

Halaman petunjuk yang ditampilkan pada Gambar 5. Pada halaman ini ditampilkan kompetensi dasar yang dimasukkan dalam media pembelajaran serta tujuan pembelajaran dari masing-masing KD.

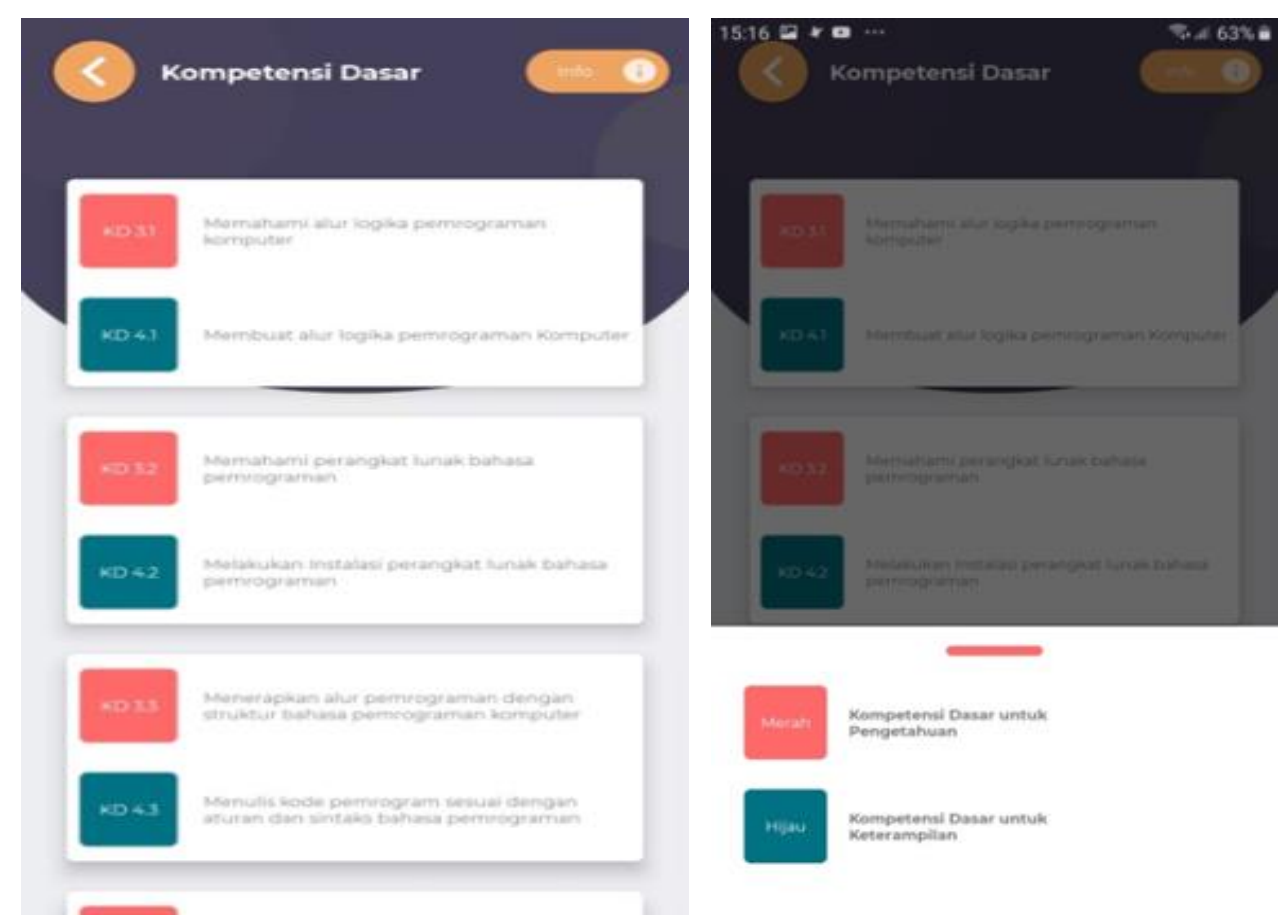

Gambar 5. Halaman dan Notifikasi untuk Menujukan Keterangan 
Pada halaman ini ditampilkan tujuan yang dimasukkan dalam media pembelajaran serta tujuan pembelajaran dari masing-masing KD.

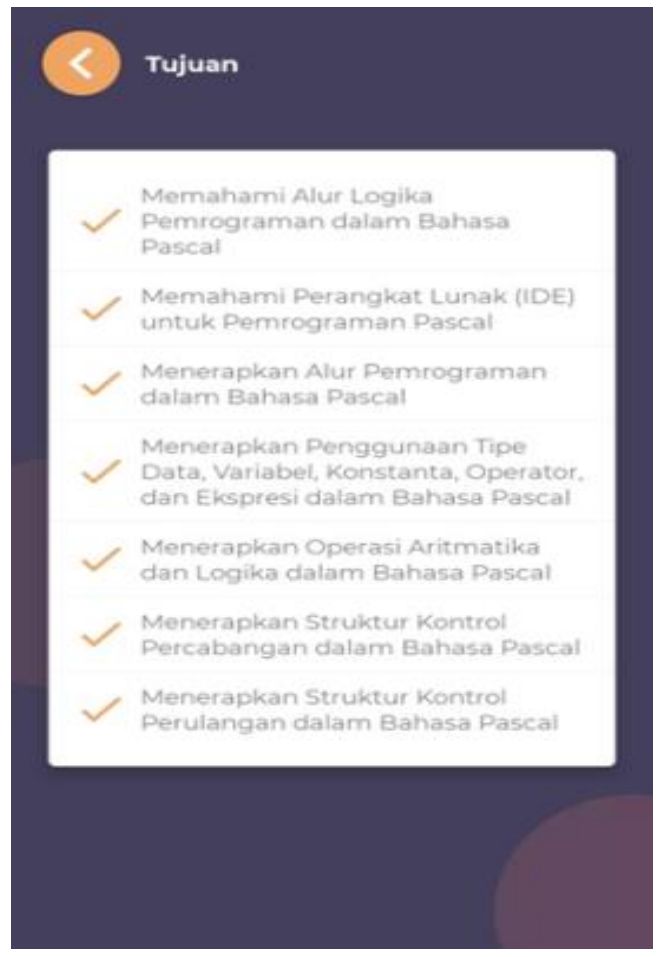

Gambar 6. Halaman Tujuan

Pada halaman ini pengguna dapat memilih materi dengan menekan tombol yang disediakan. Terdapat enam jenis materi yang disediakan berdasarkan kompetensi dasar yang dimuat seperti yang ditampilkan pada Gambar 7. halaman isi materi akan ditampilkan ketika salah satu tombol submenu materi ditekan. Halaman ini menyediakan fitur scrolling text pada pengguna untuk membaca materi.
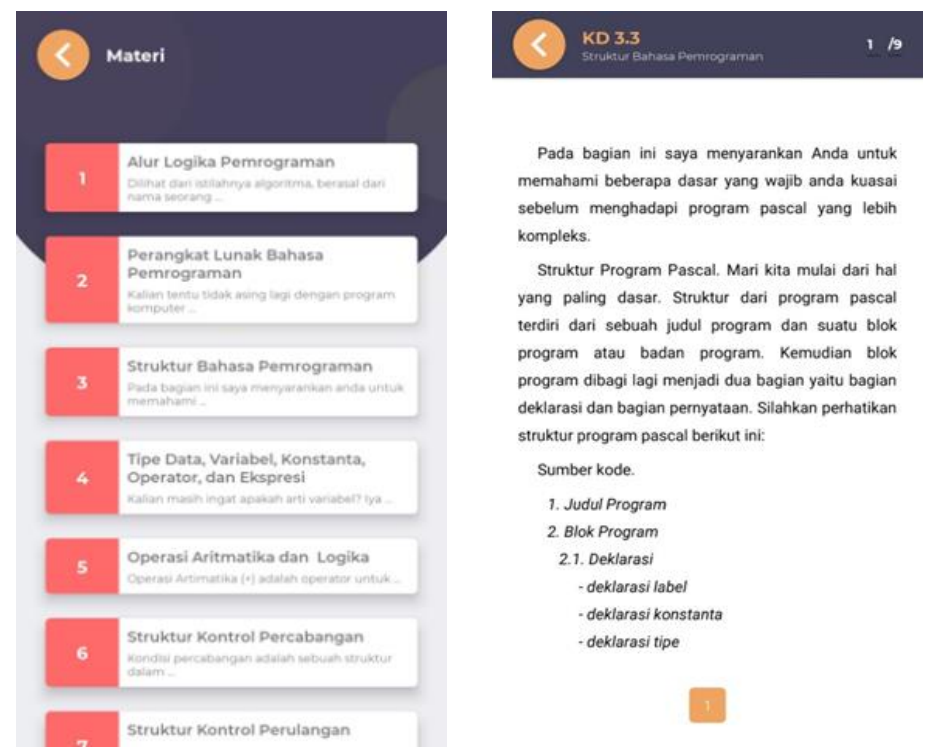

Gambar 7. Halaman Materi dan Isi Materi

Ditunjukkan halaman sub menu video berisi pilihan video pembelajaran yang disediakan pada Gambar 8. Pengguna dapat memilih video dan membukanya dengan menekan tombol play dan Gambar 8. menunjukan tampilan isi video yang dipilih.. 


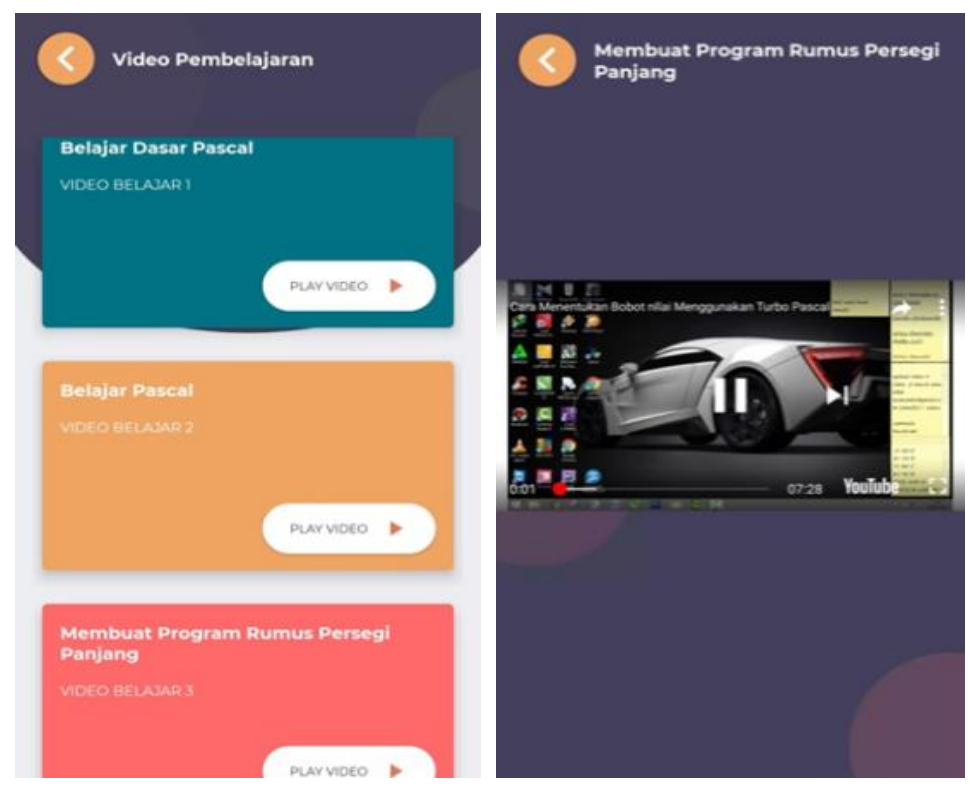

Gambar 8. Halaman Submenu Vidio dan Isi Konten Video

Pada halaman ini terdapat beberapa contoh program dari berbagai materi yang disajikan sebelumnya. Contoh program tersebut dilengkapi dengan penjelasan dan analisis, serta disajikan contoh hasil eksekusi program tersebut.

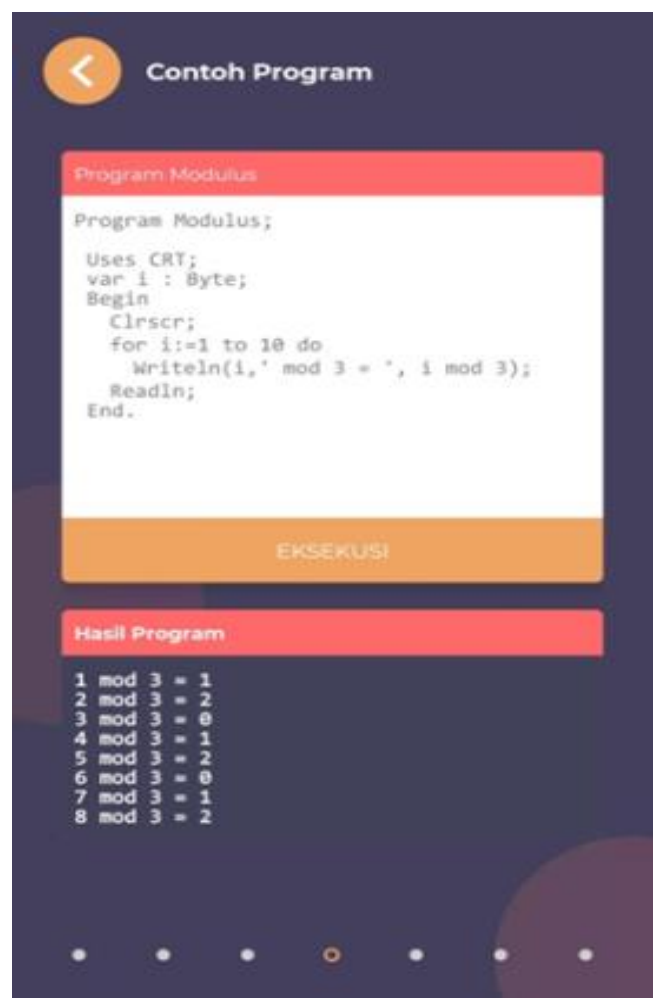

Gambar 9. Halaman Contoh Program

Seperti yang telah direncanakan dalam storyboard, halaman ini berisi tiga menu latihan soal yang disediakan. Latihan soal yang disajikan berbentuk pilihan ganda, dimana setiap soal diberikan pembahasan dan pengguna dapat melihat hasil skor setelah selesai mengerjakan. 

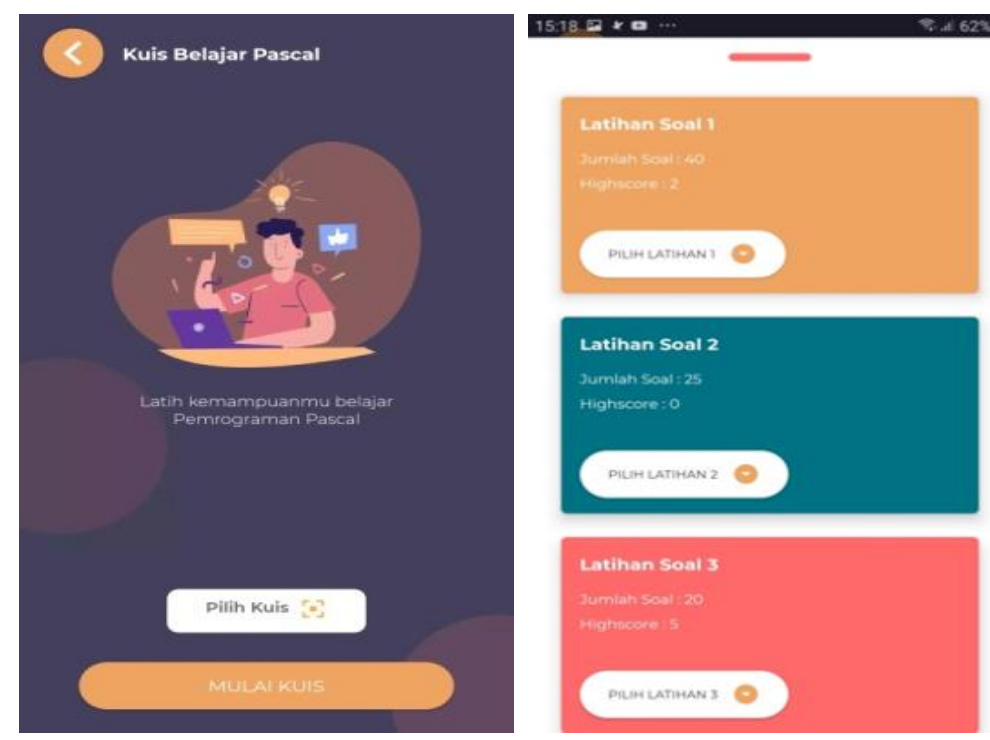

Gambar 10. Halaman Pilihan Latihhan Soal dan Submenu Latihan Soal

Pada halaman glosarium disajikan beberapa pengertian dari istilah-istilah yang sering dijumpai dalam bahasa pemrograman pascal.

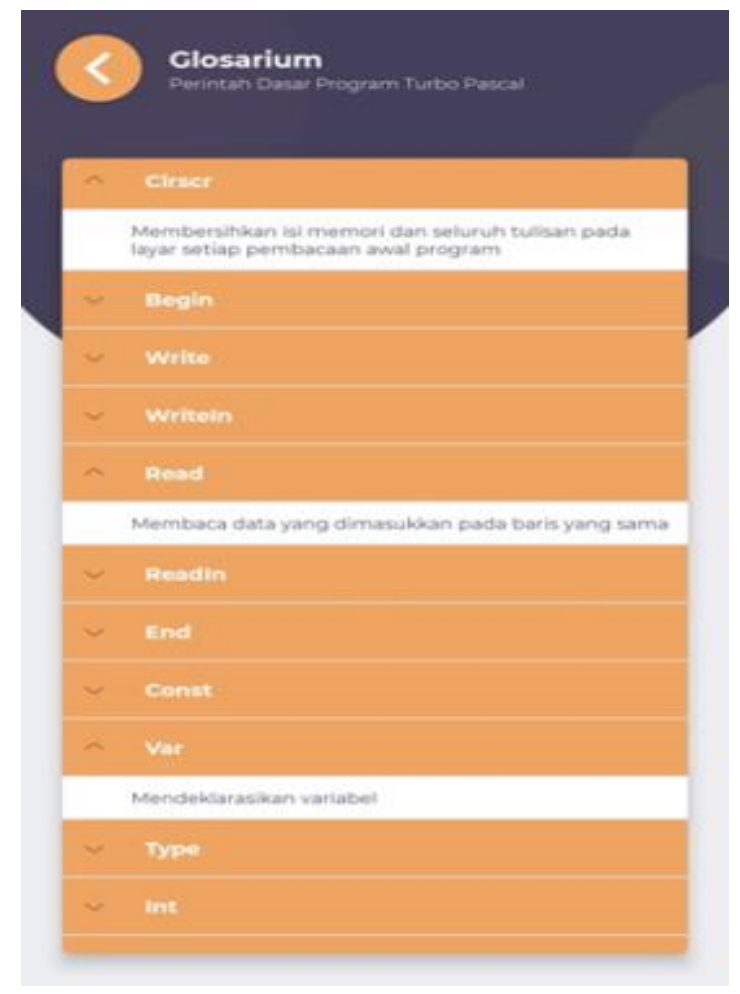

Gambar 11. Halaman Glosarium 
Halaman pengembang seperti Gambar 12. menampilkan informasi dari pengembang aplikasi, yaitu identitas pengembang dan kontak pengembang.

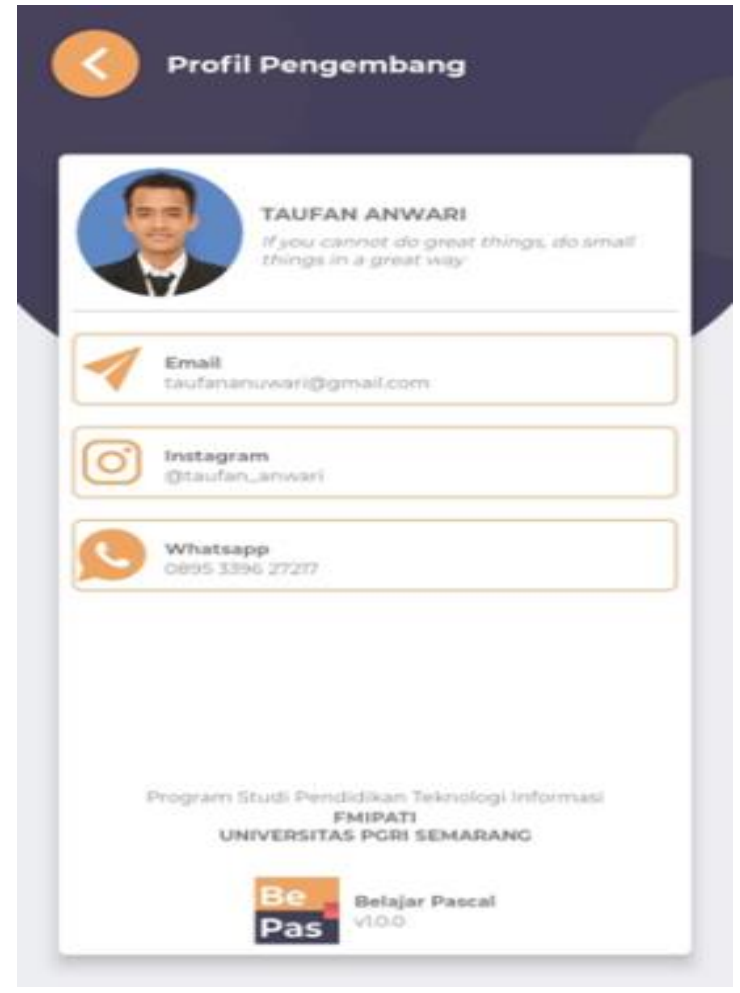

Gambar 12. Halaman Pengembang

Halaman proses pembuatan aplikasi atau frame work pada android studio

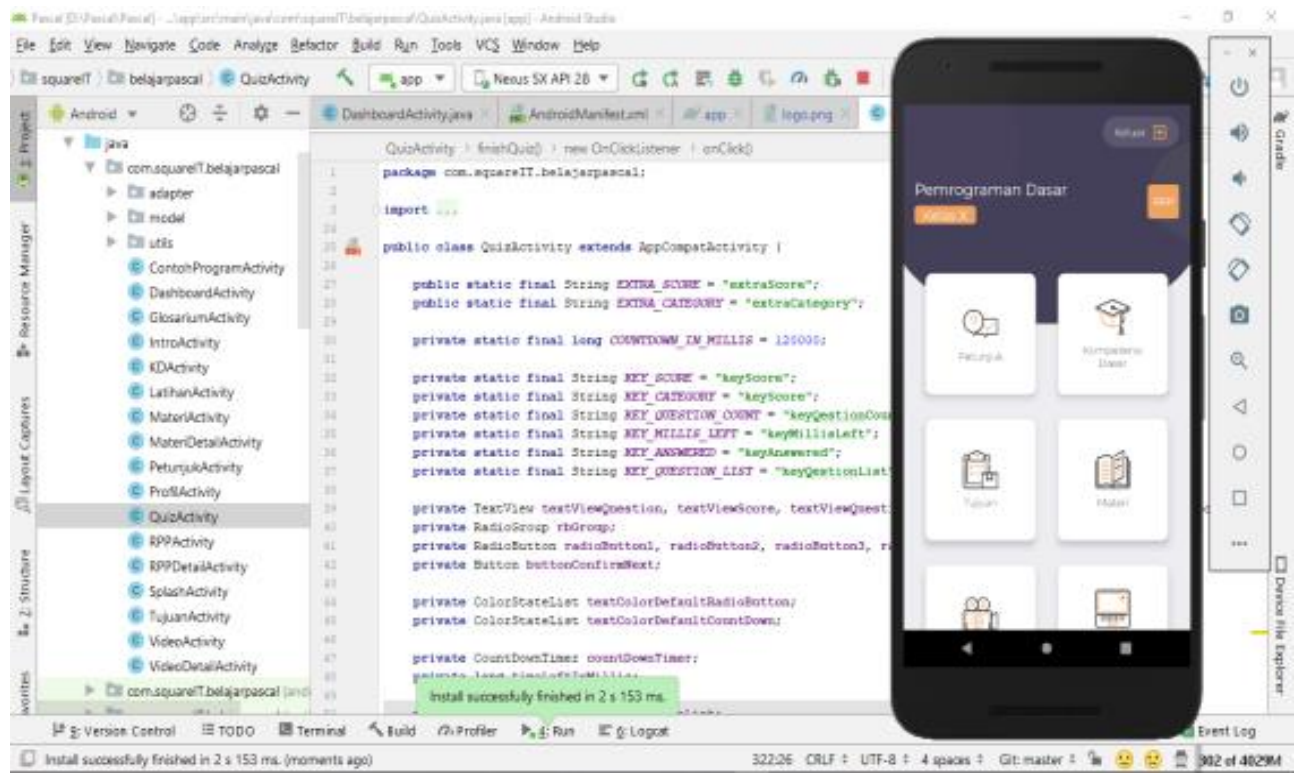

Gambar 13. Halaman Frame Work Android Studio 
Halaman tampilan input data pada database

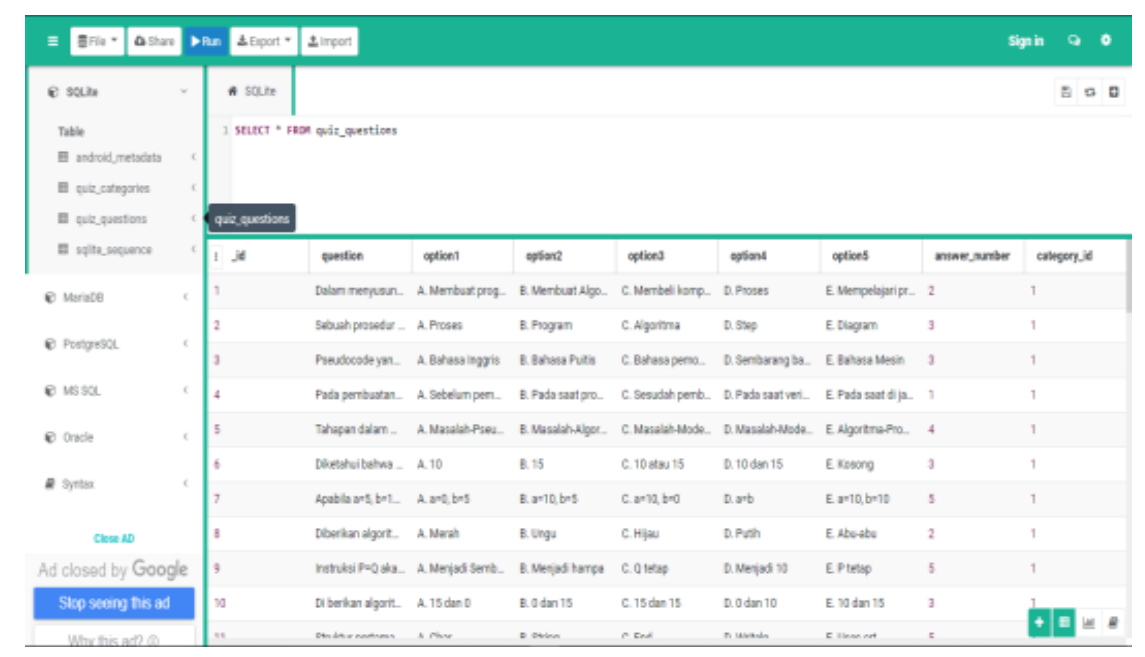

Gambar 14.Halaman pada database

\section{A. Pengujian BlackBox}

Tabel 1. Pengujian BlackBox Aplikasi PEDAS PAS

\begin{tabular}{|c|c|c|c|c|}
\hline \multirow{2}{*}{ No. } & \multirow{2}{*}{ Fungsi yang diuji } & \multirow{2}{*}{ Keterangan } & \multicolumn{2}{|c|}{ Hasil Pengujian } \\
\hline & & & Sesuai & Tidak \\
\hline & Tombol "Enter" & Menuju menu utama & $\sqrt{ }$ & \\
\hline & Tombol "Petunjuk" & Menuju halaman petunjuk & $\sqrt{ }$ & \\
\hline 3. & Tombol “KD” & Menuju halaman kompetensi dasar & $\sqrt{ }$ & \\
\hline 4. & Tombol “Tujuan” & Menuju halaman tujuan & $\sqrt{ }$ & \\
\hline & Tombol "Materi" & Menuju halaman materi & $\sqrt{ }$ & \\
\hline & Tombol "Video" & Menuju halaman video & $\sqrt{ }$ & \\
\hline & Tombol "Contoh Program" & Menuju halaman contoh program & $\sqrt{ }$ & \\
\hline & Tombol "Latihan Soal” & Menuju halaman latihan soal & $\sqrt{ }$ & \\
\hline & Tombol “Glosarium” & Menuju halaman glosarium & $\sqrt{ }$ & \\
\hline 10. & Tombol “Tentang” & Menuju halaman tentang aplikasi & $\sqrt{ }$ & \\
\hline 11. & Tombol "Info Pengembang" & Menuju halaman info pengembang & $\sqrt{ }$ & \\
\hline 13. & Tombol exit & Keluar aplikasi & $\sqrt{ }$ & \\
\hline
\end{tabular}

B. Hasil Rangkuman Uji Coba Angket Kelayakan

Berikut adalah Rekapitulasi Hasil Penilaian dari para respoden:

Tabel 2. Hasil Rekapitulasi Tiap Aspek Penilaian

\begin{tabular}{clc}
\hline No. & \multicolumn{1}{c}{ Aspek Penilaian } & Presentase Kelayakan \\
\hline 1. & Ahli media 1 & $93 \%$ \\
2. & Ahli media 2 & $76 \%$ \\
3. & Ahli materi & $76,56 \%$ \\
4. & Guru MAPEL & $77,47 \%$ \\
5. & Peserta didik & $81,4 \%$ \\
\hline \multicolumn{2}{c}{ Rata-Rata Akhir } & $\mathbf{8 0 , 8} \%$ \\
\hline
\end{tabular}

Rata-rata akhir:

$=\frac{93+76+76,56+77,47+81,4}{5}$ 
$=80,8 \%$

Berdasarkan Tabel 2. kesimpulan yang diperoleh rata-rata akhir dan presentasenya yaitu 80,8\% yang masuk ke dalam rentang Indikator yaitu 61-80 \% dengan kategori "Layak". Sehingga tingkat kelayakan media pembelajaran pemrograman dasar Pascal "PEDAS PAS-App" berdasarkan penilaian ahli dan respoden masuk ke dalam kategori "Layak".

\section{Hasil Hipotesis Data Nilai Akhir}

Menurut perhitungan data hasil belajar atau data nilai akhir menunjukkan bahwa hasil perhitungan pada kemampuan akhir nilai uji pre-test dan uji pos-test setelah mendapat perlakuan pembelajaran dengan menggunakan media pembelajaran pemrograman dasar pascal dengan model pembelajaran discovery learning nilai pre-test mengalami perbedaan.

Tabel 3. Rangkuman Hasil thitung dan ${ }^{t}$ tabel

\begin{tabular}{cccccc}
\hline Kode & $\boldsymbol{t}_{\text {hitung }}$ & $\boldsymbol{t}_{\text {tabel }}$ & Df & $\mathbf{P}$ & Kesimpulan \\
\hline test & 8,66 & 2,032 & 34 & 0,000 & Signifikan \\
\hline
\end{tabular}

Terlihat dari nilai $\alpha / 2=0,025$ dan nilai $\mathrm{df}=34$, maka nilai $\mathrm{t}$-Tabel dari penelitian saya yaitu sebesar 2,032. Berdasarkan uji perbedaan rata-rata satu pihak yaitu uji pihak kanan diperoleh thitung = 8,66 dikonsultasikan dengan ttabel pada $\alpha=5 \% \mathrm{dk}=\mathrm{n}-1$ ) $=34$ diperoleh ttabel $=2,037$ hal ini menunjukkan bahwa thitung $=8,66>$ ttabel $=2,032$, pretest $71,43<$ posttest $81,14 \mathrm{H} 0$ di tolak dan $\mathrm{H} 1$ diterima. Dari Tabel 4 diatas terlihat bahwa Sig. (2-tailed) $=0,000$. Karena nilai dari Sig. (2-tailed) kurang dari taraf signifikansi $=0,05$ yaitu 0,000 $<0,05$ maka H0 di tolak dan H1 diterima dan dapat disimpulkan bahwa ada perbedaan hasil test antara nilai pre test dan post test.

\section{KESIMPULAN}

Pengembangan media pembelajaran berbasis android pada Pemrograman dasar pascal untuk siswa kelas X SMK Negeri 9 Semarang dilakukan dengan model pengembangan ADDIE. Produk yang berhasil dikembangkan dalam pengembangan ini dengan kategori "Layak" aplikasi yang mendukung pembelajaran di kelas maupun pembelajaran mandiri, dengan memanfaatkan smartphone berbasis Android dan telah teruji kompatibel pada berbagai versi Dalam aplikasi ini terdapat fitur yang telah disesuaikan dengan kebutuhan yaitu fitur petunjuk penggunaan, materi pembelajaran, contoh program, video pembelajaran, latihan soal. teruji kelayakannya oleh ahli media 1 diperoleh rata-rata $93 \%$ dengan kategori "Sangat Layak", ahli media 2 diperoleh rata-rata 76 \% dengan kategori "Layak". Pengujian oleh ahli materi diperoleh rata-rata keseluruhan 76,56\% dengan kategori "Layak". Guru MAPEL diperoleh ratarata sebesar $77,47 \%$ dengan kategori "Layak". Adapun hasil uji kelayakan oleh peserta didik adalah 81,4\% yang termasuk dalam kategori "Layak". Perolehan rata-rata akhir keseluruhan pendapat para ahli dan responden yaitu 80,8\% dengan kategori "Layak" digunakan.

Aplikasi Media pembelajaran berbasis android pada pemrograman dasar pascal untuk siswa kelas X RPL SMK Negeri 9 Semarang dengan model pembelajaran discovery learning mengalami perbedaan yang signifikan yang di dukung dengan uji-t, dibandingkan dengan pembelajaran tanpa aplikasi edukatif berbasis android.

Dalam pengembangan aplikasi PEDAS PAS tentunya masih terdapat banyak kekurangan yang perlu dikaji dan dikembangkan kembali agar aplikasi PEDAS PAS dapat menjadi sebuah aplikasi yang sempurna, Berikut adalah saran untuk penelitian pengembangan selanjutnya: 1) Media pembelajaran berbasis Android pada Pemrograman dasar Pascal dapat dikembangkan dengan memuat kompetensi dasar dan materi yang lebih luas; 2) Media pembelajaran lebih dikembangkan dengan sistem database supaya materi dan latihan soal lebih dinamis; 3) Pengembangan media pembelajaran lebih menyediakan sarana interaksi antar pengguna. 


\section{DAFTAR PUSTAKA}

Adam, Steffi, Muhammad Taufik Syastra. 2015. Pemanfaatan Media Pembelajaran Berbasis Teknologi Informasi bagi Siswa Kelas X SMA Ananda Batam. CBIS Journal, Volume 3 No 2, Hal. 78-90. Tersedia Pada: http://ejournal.upbatam.ac.id/index.php/cbis/article/view/400.

Al-emran, Musofa, dkk. 2016. Investigating Attitudes Towards The Use of Mobile Learning in Higher Education. Elsevier Ltd.

Amirullah, Gufron, Restu Hardinata. 2017. Pengembangan Mobile Learning Bagi Pembelajaran. Jurnal Kesejahteraan Keluarga dan Pendidikan [JKKP] Vol.04 No.02 Hal. 97-101. Tersedia Pada: http://journal.unj.ac.id/unj/index.php/jkkp/article/view/4318/3246.

Arikunto, S. (2013). Prosedur Penelitian Suatu Pendekatan Praktik. Jakarta: Rineka Cipta.

Biddle, B. J., \& Rossi, P. H. (1966). The new Media and Education. Chicago: Aldine Publ.

Eko Putro Widoyoko. (2014). Evaluasi Program Pembelajaran. Yogyakarta: Pustaka Pelajar.

Endang Mulyatiningsih. (2013). Metode Penelitian Terapan Bidang Pendidikan. Bandung: Alfabeta.

Hafid, H.Abd.. 2011. Sumber dan Media Pembelajaran. Sulesana Vol. 6 No. 2 Hal. 69-78. Tersedia Pada: http://journal.uin-alauddin.ac.id/index.php/sls/article/viewFile/1403/1360.

Mahnun, Nunu. 2012. Media Pembelajaran (Kajian terhadap Langkah-Langkah Pemilihan Media dan Implementasinya dalam Pembelajaran). Jurnal Pemikiran Islam; Vol. 37, No. 1 Hal. 27-35. Tersedia Pada: http://ejournal.uin-suska.ac.id/index.php/Anida/article/viewFile/310/293.

Sunarti dan Selly Rahmawati. 2014. Penilaiandalam Kurikulum 2013. Yogyakarta:Andi Offset

Sugiyono. 2015. Metode Penelitian Pendidikan : Pendekatan Kuantitatif Kualitatif dan R n D.Bandung: CV.Alfabeta.

Sugiyono. (2016). Metode Penelitian \& Pengembangan Research and Development. Bandung: Alfabeta.

Talizaro Tafonao. 2018. Peranan Media Pembelajaran dalam Meningkatkan Minat Belajar Mahasiswa. Jurnal Komunikasi Pendidikan, Vol.2 No.2, Hal. 103-114. Tersedia Pada: http://journal.univetbantara.ac.id/index.php/komdik/article/view/113.

Zainal Arifin. (2014). Penelitian Pendidikan Metode dan Paradigma Baru. Bandung: PT Remaja Rosdakarya 